\title{
The relationship between Social Security Administrator (BPJS) regulations and the value of benefits obtained by Social Security Administrator for Employment (BPJS Ketenagakerjaan) participants
}

\author{
Resly Sistiaperdani ${ }^{1}$, Cucu Zubaedah ${ }^{1 *}$, Riana Wardani ${ }^{1}$, Ayu Trisna Hayati ${ }^{2}$, Dyah \\ Nindita Carolina ${ }^{3}$ \\ ${ }^{1}$ Department of Dental Public Health, Faculty of Dentistry Universitas Padjadjaran, Indonesia \\ ${ }^{2}$ Department of Conservative Dentistry, Faculty of Dentistry Universitas Padjadjaran Indonesia \\ ${ }^{3}$ Department of Periodontics, Faculty of Dentistry Universitas Padjadjaran, Indonesia
}

\begin{abstract}
Introduction: One of the human rights is the right to live prosperously. Indonesian government provides social security for workers, namely the Social Security Administrator for Employment (BPJS Ketenagakerjaan). Social Security Administrator for Employment has a specific set of regulations set by the government. Social Security Administrator for Employment participants obtains the value of benefits through the social security program. This study was aimed to analyse the relationship between regulations and the value of benefits obtained by BPJS Employment participants. Methods: This research was a correlational descriptive study with a survey method. Results: Most respondents stated strongly agree with the regulations of Social Security Administrator for Employment (85.09\%), and most respondents felt that they gained a lot of the value of benefits as expected $(83.80 \%)$. The results of the Spearman correlation test between the Social Security Administrator for Employment regulations with the values obtained by respondents, which resulted in $p=0.0001$ with $a=0.05$. The $p$-value that lower than the $a$ indicates a significant relationship. Conclusion: There is a relationship between the regulations of Social Security Administrator for Employment and the values obtained for the participants, with the direction of positive correlation and the moderate correlation strength.
\end{abstract}

Keywords: Social security, value of benefits, regulations of Social Security Administrator for Employment, BPJS Ketenagakerjaan.

p-ISSN: 1979-0201; e-ISSN: 2549-6212; Available from: http://jurnal.unpad.ac.id/pjd/article/view/23917

DOI: $10.24198 / \mathrm{pjd} . v 0 l 32 \mathrm{no} .23917$

Submission: Oct 25, 2019; Accepted: Jul 30, 2020; Published online: Jul 31, 2020

"Corresponding author: Cucu Zubaedah, Department of Dental Public Health, Faculty of Dentistry Universitas Padjadjaran, Indonesia. Department of Dental Public Health, Faculty of Dentistry Universitas Padjadjaran, Jalan Sekeloa Selatan I, Bandung, West Java, Indonesia, 40132. Phone: +6281321940771; Email: cucu.zubaedah@fkg.unpad.ac.id 


\section{INTRODUCTION}

Human rights are the right to an adequate standard of living for the health and welfare of an individual and families, including the right of healthy food, clothing, housing and health care, and also social services required. Everyone is also entitled to the social security when they are unemployed, suffer illness, disability, become a widow or widower, reach old age, or other conditions that result in a lack of support that is beyond their control. ${ }^{1}$

Social welfare in developed countries is called social security, such as social assistance and social insurance, which is administered by the state, especially for disadvantaged groups. In Indonesia, social welfare is often seen as a goal or condition of a prosperous life, namely the fulfilment of basic human needs. ${ }^{2}$ The state develops a social security system for all people to empower unfortunate and underprivileged people according to human dignity in the form of a national social security system, where one of the objectives is to protect workers. ${ }^{1}$

The Republic of Indonesia Health Law No. 40 of 2004 regarding the National Social Security System (SJSN) was issued, with mandatory that social security is compulsory for all residents, including National Health Insurance (JKN). The implementation of social security programs is one of the responsibilities and obligations of the state to provide socio-economic protection to the community. ${ }^{3,4}$ Social security is a form of social protection that is useful to ensure that the people of a country can fulfil their daily needs properly. The legal entity formed to administer the social security program is called the Social Security Administrator (BPJS), which consists of Social Security Administrator for Health (BPJS Kesehatan) and Social Security Administrator for Employment (BPJS Ketenagakerjaan). ${ }^{5}$

Social SecurityAdministrator for Employment is established as an agency to administer social security, with regulations set by the government. These regulations are used as guidelines in implementing social security programs that are binding the BPJS Employment participants.

The implementation of Law of the Republic of Indonesia no. 24 of 2011 concerning the Social Security Administrative Body is still weak. As suggested in the research conducted by Permana et al. ${ }^{6}$ regarding the registration of Social Security Administrator for Employment participants in Gianyar Regency, which showed a low level of Social Security Administrator for Employment participation, because from the 221,067 active workers of Gianyar Regency, only 24,425 active workers were registered as Social Secu-rity Administrator for Employment participants, which means, only $11.04 \%$ of active workers had social security for employment at the Bali Gianyar Social Security Administrator for Employment participants Branch Office.

Permana et al. ${ }^{6}$ also stated that the barriers experienced by Bali Gianyar Social Security Administrator for Employment participants Branch Office related to registration of workers in Gianyar Regency for the social security program participants was related to the value of benefits obtained by the Social Security Administrator for Employment participants. The value of benefits obtained by the Social Security Administrator for Employment participants will be affected by the set of regulations of the Social Security Administrator for Employment.

Value reflects several benefits, both tangible and intangible, and costs perceived by customers. ${ }^{7}$ The value of benefits from Social Security Administrator for Employment is obtained by participants through the social security program. The value of benefits can also be obtained in the form of the excellent services given, which proves expertise in providing quick and reliable services, clarity in providing information, and consistency in providing effective and efficient services. ${ }^{8}$

Bandung is a city with a rapid growth rate of the business sector, both large and small businesses, all of which are potential because there are workers who must be given protection from the Social Security Administrator for Employment program. Based on the hierarchy, the City Government of Bandung can provide policies that must be followed up by the district or city government regarding the implementation of Law of the Republic of Indonesia no. 24 of 2011 concerning the Social Security Administrative Body. ${ }^{9,10,11}$

This study was aimed to analyse the relationship between regulations and the value of benefits obtained by Social Security Administrator for Employment participants in Bandung City. 


\section{METHODS}

This study was a descriptive study using the survey method. The choice of this method was based on the author's need for primary data which will then be used as research subjects. The population in this study were the Social Security Administrator for Employment participants in Bandung City. The inclusion criteria were as follows: aged $18-60$ years old, active workers who have been registered as Social Security Administrator for Employment participants in Bandung City, minimum one-year membership, willing to be respondents and fill out questionnaires. The exclusion criteria were subjects with disability or mental disorders.

The research sample was the Social Security Administrator for Employment participants in Bandung City, which were chosen using the stratified random sampling technique. Stratified random sampling is a sample selection method where this method classifies the population into several groups that have the same characteristics then selects by simple random sampling the desired population member from each group member proportionally. ${ }^{12}$ This research was conducted during October - November 2018 on Social Security Administrator for Employment participants in Bandung City. The research was conducted in Bandung City, West Java, Indonesia, based on the Social Security Administrator for Employment service areas.

A questionnaire was used as a research instrument, which contained 20 questions regarding the regulations of Social Security Administrator for Employment, and questions regarding the assessment of the value of benefits obtained by the participants. Descriptive questions regarding Social Security Administrator for Employment consisted of 17 questions.

This study has two variables, namely the regulations of Social Security Administrator for Employment and the value of benefits obtained by the Social Security Administrator for Employment participants. The two variables had the following answering criteria ${ }^{13}$ : 1 is strongly disagree; 2 is disagree; 3 is doubt; 4 is agree; and 5 is strongly agree. The variable measurement scale used in this study was ordinal, namely the Likert scale. Researchers make several statements on the questionnaire, which will be distributed to respondents, then the respondents will assess the statement through several answers that have different grades or levels. All respondents' answers will be summed up based on the weight of each value. The data that will be obtained by researchers in the field was ordinal, so it was necessary to transform the data from ordinal to intervals to fulfil some of the requirements of parametric analysis-the ordinal scale data transformation was performed using the successive method. ${ }^{13,14,15}$ The statistical test used was the Spearman Rank correlation.

\section{RESULTS}

\section{Descriptive profile of respondents}

Descriptive profile of respondents that will be described in this section including the characteristics of the respondents based on sex, age range, education, and the field of work of active workers in Bandung City who were registered as participants of Social Security Administrator for Employment.

Table 1. Respondents' characteristics based on sex

\begin{tabular}{cc}
\hline Sex & Percentage \\
\hline Male & $57.5 \%$ \\
Female & $42.5 \%$ \\
\hline
\end{tabular}

Table 1 shows that the percentage of male respondents was more than female respondents. Total male respondents were $104(57.5 \%)$ and female respondents were 77 (42.5\%).

Table 2. Respondents' characteristics based on age

\begin{tabular}{cc}
\hline Age & Percentage \\
\hline $20-30$ years & $48.6 \%$ \\
$31-40$ years & $37.0 \%$ \\
$41-50$ years & $12.2 \%$ \\
$>50$ years & $2.2 \%$ \\
\hline
\end{tabular}

Table 2 shows that the majority of respondents were aged between 20-30 years, which were 88 individuals or $48.6 \%$ of the total respondents. The youngest age was 21 years ( 1 respondent), and the oldest age was 53 years ( 1 respondent).

Table 3 shows that there were four classifications of the respondents' education level, and the majority of respondents had a bachelor degree, with a total of 111 respondents (61.3\%) 
Table 3. Respondents' characteristics based on education level

\begin{tabular}{cc}
\hline Education level & Percentage \\
\hline Junior high school & $1.7 \%$ \\
Senior high school & $19.3 \%$ \\
Diploma & $17.7 \%$ \\
Bachelor & $61.3 \%$ \\
\hline
\end{tabular}

and the least respondents had a junior high school / equivalent education background, which was 3 respondents (1.7\%).

Table 4 shows that the highest percentage of the respondents' occupation was in the private sector, which was found in as many as 81 individuals (44.8\%), self-employed in 34 individuals (18.8\%), state-owned enterprises in 33 people $(18.2 \%)$, the bank in 17 individuals $(9.4 \%)$, while the remaining 16 individuals $(8.8 \%)$ were in the factory or
Table 4. Respondents' characteristics based on occupation

\begin{tabular}{cc}
\hline Occupation & Percentage \\
\hline Private employee & $44.8 \%$ \\
Self-employes & $18.8 \%$ \\
State-owned enterprise employee & $18.2 \%$ \\
Bank employee & $9.4 \%$ \\
Others (employees of factories, & $8.8 \%$ \\
manufacturers, employees of public legal \\
enterprise)
\end{tabular}

manufacture employees and employees of public legal enterprises.

\section{Respondents' assessment of the regulation variables}

Respondents' responses to the regulation variables were represented by statements of one to twenty. The processing results of the statement items are presented in Table 5.

Table 5. Respondents' responses based on regulation variables

\begin{tabular}{|c|c|c|c|c|c|c|c|c|}
\hline NO & Statement & 1 & 2 & 3 & 4 & 5 & Total & Total Score \\
\hline \multirow[b]{2}{*}{1} & Registration as a participant of Social Security & 0 & 2 & 4 & 83 & 92 & 181 & \multirow[b]{2}{*}{808} \\
\hline & $\begin{array}{l}\text { Administrator for Employment is mandatory for } \\
\text { everyone (including foreigners who have worked for } \\
\text { at least six months in Indonesia). }\end{array}$ & $0 \%$ & $1.1 \%$ & $2.2 \%$ & $45.9 \%$ & $50.8 \%$ & $100 \%$ & \\
\hline \multirow[b]{2}{*}{2} & $\begin{array}{l}\text { Employers are obligated to register their employees } \\
\text { in the employment injury insurance, old age security }\end{array}$ & 0 & 4 & 9 & 70 & 98 & 181 & \multirow[b]{2}{*}{805} \\
\hline & $\begin{array}{l}\text { program, pension program, and death insurance } \\
\text { program in Social Security Administrator for } \\
\text { Employment. }\end{array}$ & $0 \%$ & $2.2 \%$ & $5 \%$ & $38.7 \%$ & $54.1 \%$ & $100 \%$ & \\
\hline \multirow[b]{2}{*}{3} & In registering, employers are required to provide & 0 & 2 & 3 & 78 & 98 & 181 & \multirow[b]{2}{*}{815} \\
\hline & $\begin{array}{l}\text { complete and correct data on themselves, and also } \\
\text { their employees with their family members to the } \\
\text { Social Security Administrator for Employment. }\end{array}$ & $0 \%$ & $1.1 \%$ & $1.7 \%$ & $43.1 \%$ & $54.1 \%$ & $100 \%$ & \\
\hline \multirow[b]{2}{*}{4} & $\begin{array}{l}\text { Employees who work for several companies must be } \\
\text { included in the Employment Injury Insurance, Old }\end{array}$ & 0 & 0 & 9 & 69 & 103 & 181 & \multirow[b]{2}{*}{818} \\
\hline & $\begin{array}{l}\text { Age Security program, and Death Insurance program } \\
\text { by each company following the provisions of laws and } \\
\text { regulations. }\end{array}$ & $0 \%$ & $0 \%$ & $5 \%$ & $38.1 \%$ & $56.9 \%$ & $100 \%$ & \\
\hline \multirow{2}{*}{5} & $\begin{array}{l}\text { Participants who violate the provisions will be } \\
\text { subjected to administrative sanctions in the form of }\end{array}$ & 2 & 2 & 9 & 89 & 79 & 181 & \multirow{2}{*}{784} \\
\hline & $\begin{array}{l}\text { warnings, fines, and termination from getting public } \\
\text { services. }\end{array}$ & $1.1 \%$ & $1.1 \%$ & $5 \%$ & $49.2 \%$ & $43.6 \%$ & $100 \%$ & \\
\hline \multirow[b]{2}{*}{6} & Large and medium-sized businesses are obligated to & 0 & 3 & 7 & 74 & 97 & 181 & \multirow[b]{2}{*}{808} \\
\hline & $\begin{array}{l}\text { participate in the employment injury insurance, old } \\
\text { age security program, pension program, and death } \\
\text { insurance program. }\end{array}$ & $0 \%$ & $1.7 \%$ & $3.9 \%$ & $40.9 \%$ & $53.6 \%$ & $100 \%$ & \\
\hline \multirow{2}{*}{7} & $\begin{array}{l}\text { Small businesses are obligated to participate in } \\
\text { the employment injury insurance, old age security }\end{array}$ & 0 & 3 & 11 & 93 & 74 & 181 & \multirow{2}{*}{781} \\
\hline & $\begin{array}{l}\text { program, pension program, and death insurance } \\
\text { program. }\end{array}$ & $0 \%$ & $1.7 \%$ & $6.1 \%$ & $51.4 \%$ & $40.9 \%$ & $100 \%$ & \\
\hline
\end{tabular}




\begin{tabular}{|c|c|c|c|c|c|c|c|c|}
\hline \multirow{2}{*}{8} & \multirow{2}{*}{$\begin{array}{l}\text { Micro businesses are obligated to participate in the } \\
\text { employment injury insurance and death insurance } \\
\text { program. }\end{array}$} & 0 & 5 & 19 & 91 & 66 & 181 & \multirow{2}{*}{761} \\
\hline & & $0 \%$ & $2.8 \%$ & $10.5 \%$ & $50.3 \%$ & $36.5 \%$ & $100 \%$ & \\
\hline \multirow[b]{2}{*}{9} & \multirow{2}{*}{$\begin{array}{l}\text { Companies that have enrolled their workers in the } \\
\text { Social Security Administrator for Employment program } \\
\text { are prohibited from reducing every employment } \\
\text { social security program that has been registered. }\end{array}$} & 1 & 2 & 20 & 66 & 92 & 181 & \multirow[b]{2}{*}{789} \\
\hline & & $0.6 \%$ & $1.1 \%$ & $11 \%$ & $36.5 \%$ & $50.8 \%$ & $100 \%$ & \\
\hline \multirow[b]{2}{*}{10} & \multirow{2}{*}{$\begin{array}{l}\text { Everyone (other than Employers, Employees, } \\
\text { and Contribution Aid Recipients) who meet the } \\
\text { requirements for participation in the Social Security } \\
\text { program are obligated to register themselves and } \\
\text { their family members as participants in Social } \\
\text { Security Administrator for Employment. }\end{array}$} & 4 & 4 & 13 & 90 & 70 & 181 & \multirow[b]{2}{*}{761} \\
\hline & & $2,2 \%$ & $2,2 \%$ & $7,2 \%$ & $49,7 \%$ & $38,7 \%$ & $100 \%$ & \\
\hline \multirow{2}{*}{11} & \multirow{2}{*}{$\begin{array}{l}\text { The government registers Contribution Aid Recipients } \\
\text { and their family members as Participants of Social } \\
\text { Security Administrator for Employment }\end{array}$} & 3 & 8 & 16 & 87 & 67 & 181 & \multirow{2}{*}{750} \\
\hline & & $1.7 \%$ & $4.4 \%$ & $8.8 \%$ & $48.1 \%$ & $37 \%$ & $100 \%$ & \\
\hline \multirow{2}{*}{12} & \multirow{2}{*}{$\begin{array}{l}\text { In my opinion, the claim process for the Old Age } \\
\text { Security program is relatively easy }\end{array}$} & 0 & 4 & 26 & 83 & 68 & 181 & \multirow{2}{*}{758} \\
\hline & & $0 \%$ & $2.2 \%$ & $14.4 \%$ & $45.9 \%$ & $37.6 \%$ & $100 \%$ & \\
\hline \multirow{2}{*}{13} & \multirow{2}{*}{$\begin{array}{l}\text { In my opinion, the claim process for the Employment } \\
\text { Injury Insurance program is relatively easy }\end{array}$} & 0 & 1 & 8 & 28 & 92 & 181 & \multirow{2}{*}{729} \\
\hline & & $0.6 \%$ & $4.4 \%$ & $15.5 \%$ & $50.8 \%$ & $28.7 \%$ & $100 \%$ & \\
\hline \multirow{2}{*}{14} & \multirow{2}{*}{$\begin{array}{l}\text { In my opinion, the claim process for the Death } \\
\text { Insurance program is relatively easy? }\end{array}$} & 0 & 5 & 28 & 94 & 54 & 181 & \multirow{2}{*}{740} \\
\hline & & $0 \%$ & $2.8 \%$ & $15.5 \%$ & $51.9 \%$ & $29.8 \%$ & $100 \%$ & \\
\hline \multirow{2}{*}{15} & \multirow{2}{*}{$\begin{array}{l}\text { In my opinion, the claim process for the Pension } \\
\text { Insurance program is relatively easy? }\end{array}$} & 0 & 9 & 21 & 96 & 55 & 181 & \multirow{2}{*}{740} \\
\hline & & $0 \%$ & $5 \%$ & $11.6 \%$ & $53 \%$ & $30.4 \%$ & $100 \%$ & \\
\hline \multirow{2}{*}{16} & \multirow{2}{*}{$\begin{array}{l}\text { In my opinion, fulfilling the claim requirements in the } \\
\text { Old Age Security program is relatively easy? }\end{array}$} & 0 & 8 & 15 & 95 & 63 & 181 & \multirow{2}{*}{756} \\
\hline & & $0 \%$ & $4.4 \%$ & $8.3 \%$ & $52.5 \%$ & $34.8 \%$ & $100 \%$ & \\
\hline \multirow{2}{*}{17} & \multirow{2}{*}{$\begin{array}{l}\text { In my opinion, fulfilling the claim requirements in the } \\
\text { Pension Insurance program is relatively easy? }\end{array}$} & 0 & 6 & 18 & 98 & 59 & 181 & \multirow{2}{*}{753} \\
\hline & & $0 \%$ & $3.3 \%$ & $9.9 \%$ & $54.1 \%$ & $32.6 \%$ & $100 \%$ & \\
\hline \multirow{2}{*}{18} & In my opinion, fulfilling the claim requirements in the & 0 & 7 & 33 & 96 & 45 & 181 & \\
\hline & $\begin{array}{l}\text { Employment Injury Insurance program is relatively } \\
\text { easy? }\end{array}$ & $0 \%$ & $3.9 \%$ & $18.2 \%$ & $53 \%$ & $24.9 \%$ & $100 \%$ & 722 \\
\hline 19 & In my opinion, fulfilling the claim requirements in the & 0 & 5 & 34 & 96 & 46 & 181 & 726 \\
\hline 19 & Death Insurance program is relatively easy? & $0 \%$ & $2.8 \%$ & $18.8 \%$ & $53 \%$ & $25.4 \%$ & $100 \%$ & $1 / 20$ \\
\hline & Social Security Administrator for Employment pays & 0 & 3 & 12 & 74 & 92 & 181 & \\
\hline 20 & $\begin{array}{l}\text { the } \text { ord Age security benefits at once to participants } \\
\text { or the participant is deceased. }\end{array}$ & $0 \%$ & $1.7 \%$ & $6.6 \%$ & $40.9 \%$ & $50.8 \%$ & $100 \%$ & 198 \\
\hline & Total & & & & & & & 15.402 \\
\hline & & & & & & & & $85.09 \%$ \\
\hline
\end{tabular}

From the data presented in Table 3, the total score percentage of the regulations variable was $85.09 \%$. Figure 1 will presented the total score after applied to the continuum line.

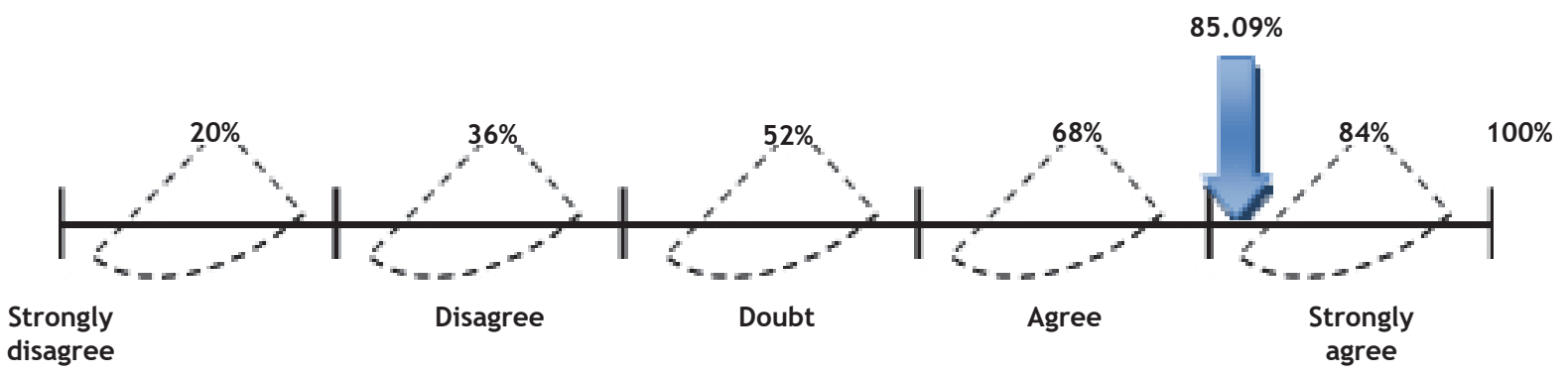

Figure 1. The percentage of the regulation variable in the continuum line 


\section{Respondents' assessment of the value of} benefits variables

Respondents' responses to the participation value of benefits variable were represented by statements one to seventeen. The processing results of the statement items contained in the variables are presented in Table 6.

Table 6. Respondents' responses based on value of benefits variables

\begin{tabular}{|c|c|c|c|c|c|c|c|c|}
\hline No & Statement & 1 & 2 & 3 & 4 & 5 & Total & Total score \\
\hline \multirow[b]{2}{*}{1} & In my opinion, the registration process to become a Social & 0 & 5 & 16 & 74 & 86 & 181 & \multirow[b]{2}{*}{784} \\
\hline & $\begin{array}{l}\text { Security Administrator for Employment participant is } \\
\text { relatively easy }\end{array}$ & $0 \%$ & $2.8 \%$ & $8.8 \%$ & $40.9 \%$ & $47.5 \%$ & $100 \%$ & \\
\hline \multirow{2}{*}{2} & \multirow{2}{*}{$\begin{array}{l}\text { In my opinion, getting a Social Security Administrator for } \\
\text { Employment card/certificate is relatively easy }\end{array}$} & 0 & 6 & 20 & 74 & 81 & 181 & \multirow{2}{*}{773} \\
\hline & & $0 \%$ & $3.3 \%$ & $11 \%$ & $40.9 \%$ & $44.8 \%$ & $100 \%$ & \\
\hline \multirow[b]{2}{*}{3} & \multirow{2}{*}{$\begin{array}{l}\text { In my opinion, the registration process to become a Social } \\
\text { Security Administrator for Employment participant is on } \\
\text { appropriate time. }\end{array}$} & 0 & 5 & 16 & 83 & 77 & 181 & \multirow[b]{2}{*}{775} \\
\hline & & $0 \%$ & $2.8 \%$ & $8.8 \%$ & $45.9 \%$ & $42.5 \%$ & $100 \%$ & \\
\hline \multirow[b]{2}{*}{4} & \multirow{2}{*}{$\begin{array}{l}\text { In my opinion, there are many benefits when becoming } \\
\text { the participants of the Social Security Administrator for } \\
\text { Employment }\end{array}$} & 0 & 3 & 17 & 65 & 96 & 181 & \multirow[b]{2}{*}{797} \\
\hline & & $0 \%$ & $1.7 \%$ & $9.4 \%$ & $35.9 \%$ & $53 \%$ & $100 \%$ & \\
\hline \multirow[b]{2}{*}{5} & \multirow{2}{*}{$\begin{array}{l}\text { The contributions paid are following the income/wages } \\
\text { of the Social Security Administrator for Employment } \\
\text { participants }\end{array}$} & 1 & 4 & 31 & 84 & 64 & 184 & \multirow[b]{2}{*}{758} \\
\hline & & $0.6 \%$ & $2.2 \%$ & $17.1 \%$ & $46.4 \%$ & $33.7 \%$ & $100 \%$ & \\
\hline \multirow[b]{2}{*}{6} & \multirow{2}{*}{$\begin{array}{l}\text { The contributions paid are following the benefits provided } \\
\text { in every Social Security Administrator for Employment } \\
\text { program }\end{array}$} & 0 & 3 & 20 & 91 & 67 & 181 & \multirow[b]{2}{*}{765} \\
\hline & & $0 \%$ & $1.7 \%$ & $11 \%$ & $50.3 \%$ & $37 \%$ & $100 \%$ & \\
\hline \multirow[b]{2}{*}{7} & \multirow{2}{*}{$\begin{array}{l}\text { The contributions paid are following the services provided } \\
\text { in every Social Security Administrator for Employment } \\
\text { program }\end{array}$} & 0 & 4 & 25 & 83 & 69 & 181 & \multirow[b]{2}{*}{760} \\
\hline & & $0 \%$ & $2.2 \%$ & $13.8 \%$ & $45.9 \%$ & $38.1 \%$ & $100 \%$ & \\
\hline \multirow{2}{*}{8} & \multirow{2}{*}{$\begin{array}{l}\text { Participants who are late in paying contributions per month } \\
\text { will be given sanctions. }\end{array}$} & 3 & 11 & 26 & 75 & 66 & 181 & \multirow{2}{*}{733} \\
\hline & & $1.7 \%$ & $6.1 \%$ & $14.4 \%$ & $41.4 \%$ & $36.5 \%$ & $100 \%$ & \\
\hline \multirow{2}{*}{9} & \multirow{2}{*}{ The process of paying contributions is easy. } & 1 & 2 & 32 & 77 & 69 & 181 & \multirow{2}{*}{754} \\
\hline & & $0.6 \%$ & $1.1 \%$ & $17.7 \%$ & $42.5 \%$ & $38.1 \%$ & $100 \%$ & \\
\hline 10 & The benefits obtained by participants in the Old Age & 2 & 1 & 25 & 75 & 78 & 181 & \\
\hline 10 & Security program are appropriately expected. & $1.1 \%$ & $0.6 \%$ & $13.8 \%$ & $41.4 \%$ & $43.1 \%$ & $100 \%$ & \\
\hline 11 & The benefits obtained by participants in the Pension & 1 & 4 & 24 & 80 & 72 & 181 & \\
\hline 11 & Insurance program are appropriately expected. & $0.6 \%$ & $2.2 \%$ & $13.3 \%$ & $44.2 \%$ & $39.8 \%$ & $100 \%$ & 101 \\
\hline 12 & The benefits obtained by participants in the Old Age & 0 & 8 & 25 & 77 & 71 & 181 & 754 \\
\hline 12 & Security Pension program are appropriately expected. & $0 \%$ & $4.4 \%$ & $13.8 \%$ & $42.5 \%$ & $39.2 \%$ & $100 \%$ & 104 \\
\hline 12 & The benefits obtained by participants in the Disability & 1 & 7 & 28 & 84 & 61 & 181 & \\
\hline 13 & Pension Plan program are appropriately expected. & $0.6 \%$ & $3.9 \%$ & $15.5 \%$ & $46.4 \%$ & $33.7 \%$ & $100 \%$ & \\
\hline 49 & The benefits obtained by participants in the Child Pension & 1 & 5 & 30 & 92 & 53 & 181 & \\
\hline 14 & program are appropriately expected. & $0.6 \%$ & $2.8 \%$ & $16.6 \%$ & $50.8 \%$ & $29.3 \%$ & $100 \%$ & 104 \\
\hline 15 & The benefits obtained by participants in the Widow/ & 1 & 11 & 28 & 85 & 56 & 181 & \\
\hline 10 & Widower Pension program are appropriately expected. & $0.6 \%$ & $6.1 \%$ & $15.5 \%$ & $47 \%$ & $30.9 \%$ & $100 \%$ & \\
\hline & Benefits of reimbursement of medical expenses, & 1 & 7 & 18 & 90 & 65 & 181 & \\
\hline 16 & $\begin{array}{l}\text { transportation, and compensation in the Employment Injury } \\
\text { Insurance program are as expected by participants. }\end{array}$ & $0.6 \%$ & $3.9 \%$ & $9.9 \%$ & $49.7 \%$ & $35.9 \%$ & $100 \%$ & 754 \\
\hline 17 & Death benefits or compensations in Death Security program & 0 & 8 & 22 & 83 & 68 & 181 & \\
\hline 17 & are following what is expected by the participants. & $0 \%$ & $4.4 \%$ & $12.2 \%$ & $45.9 \%$ & $37.6 \%$ & $100 \%$ & \\
\hline & Total score & & & & & & & 12892 \\
\hline & Total score percentage & & & & & & & $83.80 \%$ \\
\hline
\end{tabular}


The total score percentage of the value of benefits variable was $83.80 \%$. Figure 2 will presents the total score percentage of the value of benefits after applied to the continuum line.

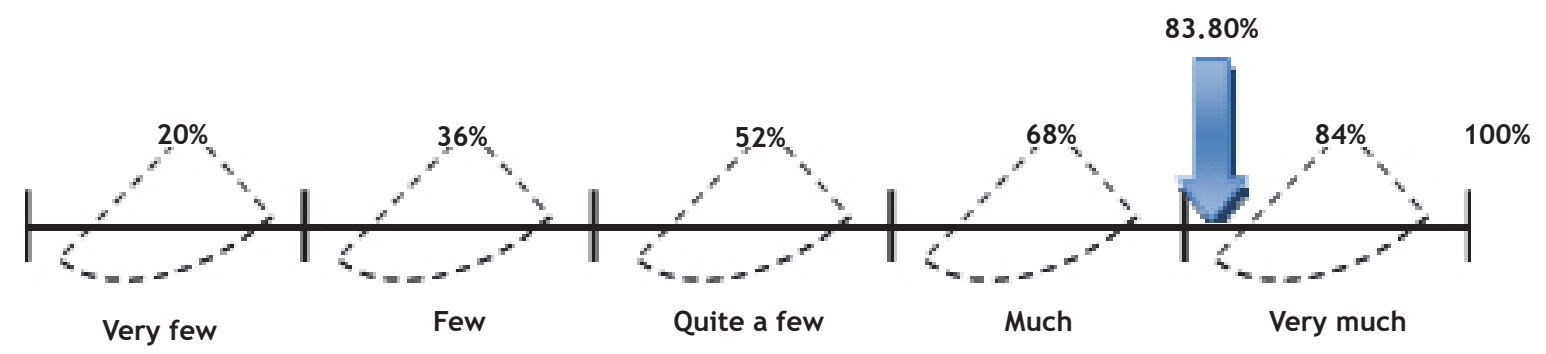

Figure 2. The percentage of the value of benefits variable in the continuum line

Table 7. Hypothesis test

\begin{tabular}{|c|c|c|c|c|c|}
\hline Variable & Total regulations score & Total value of benefits score & Correlation & $r$ & $\mathrm{p}$-value \\
\hline Mean \pm Std & $68.26 \pm 11.937$ & $60.56 \pm 11.777$ & Spearman & 0.644 & $0.0001^{* *}$ \\
\hline Median & 68.87 & 60.05 & & & \\
\hline Range (min-max) & $32.30-87.60$ & $29.43-77.40$ & & & \\
\hline
\end{tabular}

From the continuum line of mean values, it can be concluded that the overall value of the value of benefits variables was $83.80 \%$, with the category of a lot, meaning that all indicators of the variables were applied properly.

\section{Hypothesis test}

As shown in Table 7, the results of Spearman's correlation test between the total regulations variable score and the total value of benefits score resulting in a significant value $(\mathrm{p}$-value $=0.0001$; $\mathrm{p}<0.05$ ).

This result shows a significant or statistically significant correlation, so it can be concluded that there is a correlation between each total regulations variable score and the total value of benefits score. The correlation coefficient (R) showed positive correlation direction with moderate correlation strength. The results of the Spearman statistical analysis for the correlation value of the total regulations score, resulting in the score of $0.644 ; p$-value $=0.0001$. The Guilford criteria was conducted In order to determine the closeness of the relationship. It can be concluded that there was a moderate and significant correlation between the total regulations score and the total value of benefits score of the Social Security Administrator for Employment in Bandung City.

\section{DISCUSSION}

The results of the research that have been conducted show that most respondents answered strongly agree with the membership rules set by the Social Security Administrator for Employment. Judging from Table 5 which consists of 11 statements containing the membership rules for the Social Security Administrator for Employment, the most respondents answered strongly agree with the statement of the rules for Social Security Administrator for Employment submitted to respondents.

The rules for the Social Security Administrator for Employment include regulations that require everyone to be registered as a participant in the Social Security Administrator for Employment (including foreigners who have worked for at least six months in Indonesia), employer regulations must register their workers in the Work Accident Insurance program, Old-age security, pension program, and death security program in stages, and must provide complete and correct data on himself and his employees and their family members. The next regulation, namely the regulation of workers who work for several companies, must be included in the Work Accident Security and Death Security program by each company under the provisions of laws 
and regulations, including large businesses, medium enterprises, small businesses and microenterprises.

Respondents also stated that they strongly agreed with the government regulation that registers contribution assistance recipients and their family members as participants of the Social Security Administrator for Employment, and respondents also agreed with the existence of regulations that violate the provisions of being subject to administrative sanctions in the form of warnings, fines, and termination of getting public services. This result shows that respondents as active workers as participants in the Social Security Administrator for Employment have accepted and understood that the applicable regulations and stipulated in the implementation of the Social Security Administrator for Employment as a public service program are the implementation of the laws and regulations of the Republic of Indonesia government legally so that workers who are also citizens of the Republic of Indonesia are obliged to obey these regulations.

The results of the research and interviews with researchers also showed that respondents realized that by registering as a participant in the Social Security Administrator for Employment, they would increase productivity at work because they created a sense of security and comfort, avoiding risks in the work environment that might be faced. A similar result also supported by Wiranta ${ }^{16}$, who stated that another benefit felt by companies that register their workers as participants in the Social Security Administrator for Employment is to increase workers' loyalty to the company which will have a positive impact on work productivity for both the company and workers and will encourage increased work efficiency.

Some respondents stated that they disagreed with the existence of employer regulations when registering, they were required to provide complete and correct data of themselves and their workers and their family members to the Social Security Administrator for Employment, rules of participants who violated the provisions were subject to administrative sanctions in the form of warnings, fines, and termination from getting public service. Some respondents also stated that they disagreed with the existence of company regulations that included workers in the workforce social security program, they were prohibited from reducing the workforce social security program that had been followed and did not agree with the existence of regulations for everyone (other than employers, workers, and contribution assistance recipients) who meet the membership requirements in the social security program must register themselves and their family members as participants in the Social Security Administrator for Employment.

The results of the research and interviews of researchers in the present study revealed that some respondents disagreed with the existence of several Social Security Administrator for Employment regulations because employers felt it was too hard to register all workers regarding the number of contributions to be paid. This result was also supported by the existence of employers' perceptions that an occupational accident is something that is not certain to happen so that some respondents felt that they did not need protection and objected if all their employees are obligated to be registered as Social Security Administrator for Employment participants. This result was supported by Luthfiana ${ }^{18}$ which stated that although the benefits of the Social Security Administrator for Employment are significant for the protection of workers, there are still many business owners who do not register their employees. The reason why companies are negligent in their obligations, especially in the workers' social security program, is due to factors such as costs, daily workers, contract workers, and small and medium-sized enterprises. ${ }^{17}$ Other research results that support this statement is the need for socialisation to employees and the public regarding a more progressive Social Security Administrator for Employment program to anticipate fraud committed by business owners by not paying mandatory contributions as the rights of workers. ${ }^{18}$ Lack of socialisation about the Social Security Administrator for Employment program to the public has resulted in many companies not registering their employees as participants in the Social Security Administrator for Employment program. Companies that do not include their employees in the Social Security Administrator for Employment program are tantamount to ignoring the rule of law and violating human rights. ${ }^{18}$ 
The next indicator is the level of convenience in the claims service process and the requirements for submitting claims for all social security programs (old age security insurance, employment injury insurance, pension security, and death security), where the Social Security Administrator for Employment has also regulated the implementation of these two things.

The results of research and interviews show that most respondents answer the claims service process and the requirements for submitting claims that have been regulated by the Social Security Administrator for Employment are at the easy level for all social security programs (old age security insurance, employment injury insurance, pension security, and death security). The regulations that apply to the claim process and the requirements for submitting claims mean that it is considered not burdensome for respondents as active participants of the Social Security Administrator for Employment. The results of this study are also supported by the results of a survey conducted by the Social Security Administrator for Employment that the Customer Satisfaction Index (CSI) in the claims service process for the Old Age Security program is $97.58 \%$, the Employment Injury Insurance program is $96.29 \%$, the Pension Security program is $98.8 \%$, and the Death Security program is $98.65 \% .{ }^{17}$

A critical aspect in the implementation of social security is that there is interdependence between actors and the system, namely the workforce community as an actor and the Social Security Administrator for Employment service as a system. ${ }^{19}$ The guidelines for implementing social security should not be burdensome for participants due to dependency, which must be mutually beneficial between the two parties. Ease in the claim service process and requirements for submitting claims are also considered very important considering that there is one of the Social Security Administrator for Employment programs, namely Work Accident Insurance which requires fast handling in the event of an accident on the way from home to work or vice versa, an accident while at work, workplace and diseases caused by the work environment. ${ }^{20}$

The results of the research and subsequent interviews, most respondents stated that there was an ease in the registration process to become a participant and the process of obtaining a Social Security Administrator for Employment card/certificate. The results also show that the registration process to become a participant in the Social Security Administrator for Employment is at a fast rate and the benefits obtained when participating in the Social Security Administrator for Employment are at a very high level, besides that, the contributions paid by participants are felt to be following their income. Participants' wages and contributions paid are following the benefits and services provided in each Social Security Administrator for Employment program, and respondents also stated that the process of paying contributions is easy. The results of this study are also supported by the results of a survey conducted by the Social Security Administrator for Employment, the Customer Satisfaction Index (CSI) for administrative processes and participation of $91.32 \%$ which indicates that they are at a very good level. ${ }^{17}$

The research conducted by Saad ${ }^{21}$ shows that the Work Accident Security (JKK) program, both in terms of services and programs, have increased a lot after being transformed from Jamsostek to Social Security Administrator for Employment. Changes in rules that are accompanied by an increase in the intended value include participation that was previously only for formal sector workers but now has increased to the formal and informal sectors, contributions, additional programs such as Return to Work (a program where when workers experience physical disabilities during work accidents, participants will get job training so that you can return to work in addition to getting compensation money), and increased benefits such as medical expenses which previously were only paid a maximum of twenty million rupiahs but now medical and treatment costs are covered until recovery and replacement of dentures, which is a maximum of only two million rupiahs, now becomes three million rupiahs. ${ }^{21}$ Another benefit, seen from the survey results of Social Security Administrator for Employment participants, $63.44 \%$ stated that they were satisfied with the satisfaction of Trauma Center services at the hospital in collaboration with the Social Security Administrator for Employment. ${ }^{17}$ This result also shows that there is a relationship between the regulations and the scores obtained by the 
Social Security Administrator for Employment participants. Changes in regulations have also led to an increase in the scores obtained by the Social Security Administrator for Employment participants, thus supporting the results of this study.

The results of this study also show that there is a relationship between the rules and the scores obtained by the Social Security Administrator for Employment participants, this can be seen from the results which state that most respondents strongly agree with the rules. The results indicate that most respondents feel the value obtained is already a lot. According to the respondent's expectations, it shows that the respondent has agreed to these rules because they have realized that there are many points that the respondent will get if he becomes a participant in the Social Security Administrator for Employment, besides that, the respondent who has obeyed the rules that have been set means that they already know and feel the value obtained by the Social Security Administrator for Employment participants. This result was also supported by the results of a survey conducted by the Social Security Administrator for Employment that the level of participants' understanding of the rules of the Social Security Administrator for Employment and the benefits of the Social Security Administrator for Employment program, the most respondents, namely $61.75 \%$ already understand these two things. Other survey results that support the results of this research are in the Customer Satisfaction Index (CSI) for Social Security Administrator for Employment participants in 2017 which states that the level of participant satisfaction with the Social Security Administrator for Employment program and the scores obtained by participants has increased from 2016 -amounting to $88.20 \%$ to $90.71 \%$ in 2017 in line with the clarity of regulations and understanding of participants, which led to a significant increase in benefits. ${ }^{17}$

\section{CONCLUSION}

There is a relationship between the regulations of Social Security Administrator for Employment and the values obtained for the participants, with the direction of positive correlation and the moderate correlation strength.

\section{REFERENCES}

1. Situmorang $\mathrm{CH}$. Reformasi Jaminan Sosial Di Indonesia: Transformasi BPJS: Indahnya Harapan Pahitnya Kegagalan. Jakarta: Cinta Indonesia; 2013. p. 7.

2. Suharto E. Analisis Kebijakan Publik: Panduan Praktis Mengkaji Masalah dan Kebijakan Sosial. Bandung: Alfabeta; 2005. p. 238.

3. Husni L. Pengantar Hukum Ketenagakerjaan. $14^{\text {th }}$ ed. Jakarta: PT RajaGrafindo Persada; 2016. p. 27.

4. Regulation of the Minister of Manpower of the Republic of Indonesia No. 1 of 2016. Ministry of Manpower of the Republic of Indonesia. Jakarta; 2016. pp. 1-28.

5. The Republic of Indonesia Health Law No. 40 of 2004 on National Social Security System. Ministry of Health of the Republic of Indonesia. Jakarta; 2016. pp. 1-26.

6. Permana IPYI, Suyatna IN, Sarna K. Implementasi Undang-Undang nomor 24 tahun 2011 tentang Badan Penyelenggara Jaminan Sosial Ketenagakerjaan terkait pendaftaran peserta program Jaminan Sosial Ketenagakerjaan di Kabupaten Gianyar. Kertha Negara J Ilm Hukum. 2017; 5(2): 1-14.

7. Kotler P, Keller KL. Marketing Management. 14 $4^{\text {th }}$ ed. New Jersey: Prentice Hall; 2012. p. 12.

8. Hidayah LN, Santoso T. Kualitas pelayanan Badan Penyelenggara Jaminan Sosial (BPJS) Ketenagakerjaan (Studi tentang pemberian pelayanan BPJS Ketenagakerjaan bagi tenaga kerja di Kantor BPJS Cabang Rungkut Surabaya). J Penelit Admin Publik. 2015; 1(1): 97-111. DOI: 10.30996/jpap.v1i01.398

9. The 1945 Constitution of the Republic of Indonesia Article 28 paragraph 3. Jakarta; 1945.

10. The 1945 Constitution of the Republic of Indonesia Article 34 paragraph 1. Jakarta; 1945.

11. Law Number 3 of 1992 on Employee Social Security. President of the Republic of Indonesia. Jakarta; 1992. pp. 1-12.

12. Yusuf AM. Metode Penelitian Kuantitatif, Kualitatif \& Penelitian Gabungan. Jakarta: Prenada Media; 2016. p. 171. 
13. Dahlan MS. Statistik untuk Kedokteran dan Kesehatan: Deskriptif, Bivariat, dan Multivariat dilengkapi Aplikasi dengan Menggunaan SPSS. $3^{\text {rd }}$ ed. Jakarta: Salemba Medika; 2008. pp. 4-11.

14. Umar H. Metode Penelitian untuk Skripsi dan Tesis Bisnis. Jakarta: RajaGrafindo Persada; 2008. pp. 168-9.

15. Sudjana. Metoda Statistika. $7^{\text {th }}$ ed. Bandung: Tarsito; 2013. pp. 172-3, 455-7.

16. Wiranta S. Peningkatan Kesejahteraan dan Perlindungan Pekerja Melalui Program Jamsostek. Jakarta: LIPI Press; 2009. pp. 1-68.

17. Luthfiana U. Perlindungan hukum terhadap pekerja/buruh penerima upah dalam suatu perusahaan yang tidak diikutsertakan dalam keanggotaan BPJS Ketenagakerjaan ditinjau dari Undang-Undang nomor 24 tahun 2011 tentag BPJS. J Hukum Progresif. 2016; 10(1):
1658-70. DOI: $10.33019 /$ progresif.v10i1.181

18. Retno PA. Perancangan Iklan Komersial untuk Menarik Minat Kepesertaan BPJS Ketenagakerjaan di wilayah cabang Semarang Majapahit [minor thesis]. Semarang: Dian Nuswantoro University; 2016. p. 8.

19. Sztompka P. The Sociology of Social Change. Hoboken: John Wiley \& Sons, Inc; 1993. pp. 1-383.

20. Government Regulations No. 44 of 2015 concerning the Organization of Occupational Accident Insurance and Death Benefits. Ministry of Manpower of the Republic of Indonesia. Jakarta; 2015. pp. 11-82.

21. Saad MY. Tinjauan Yuridis Penyelenggaraan Program Badan Penyelenggara Jaminan Sosial (BPJS) Ketenagakerjaan [minor thesis]. Makassar: Hasanuddin University; 2016. pp. 1-64. 